\title{
Pengembangan Aplikasi Kasir Menggunakan Model Waterfall
}

\author{
Aji Saputra ${ }^{1}$, Cut Fera Inong Safitri ${ }^{2}$, Fitriyani $^{3}$, Yarni Gulo ${ }^{4}$, Teti Desyani ${ }^{5}$ \\ Teknik Informatika, Universitas Pamulang, Tangerang Selatan, Indonesia, 15417 \\ e-mail: ${ }^{1}$ jisaputraa2gmail.com, ${ }^{2}$ cutferainongs@gmail.com, ${ }^{3}$ fitriyanifiya17@gmail.com, \\ 4yarniwati21@gmail.com, ${ }^{5}$ dosen00839@unpam.ac.id \\ Submitted Date: April 06 ${ }^{\text {th }}, 2021$ \\ Revised Date: July $05^{\text {th }}, 2021$ \\ Reviewed Date: April $11^{\text {th }}, 2021$ \\ Accepted Date: April $06^{\text {th }}, 2021$
}

\begin{abstract}
Many companies engaged in printing services still use manual processes in their transactions, the system process is less efficient and the possibility of errors in input data can still occur. Like the process of recording orders using paper, calculations using calculators and sales transactions written on books. Therefore, for these problems, a cashier application is needed that can facilitate the order process, calculations and transactions accurately with a web-based cashier application that features login, sales transactions, product data, add products, settings and exit applications. Our development process uses the waterfall method and to describe the system design we use the Unified Modeling Language (UML). Application using the waterfall method can make it easier to complete the application development process because there are already stages in the method.
\end{abstract}

Keywords: Cashier Application; Web-Based Application; Waterfall; UML; Unified Modeling Language

\begin{abstract}
Abstrak
Perusahaan yang bergerak dalam bidang jasa percetakan masih banyak yang menggunakan proses manual dalam transaksinya, proses sistem tersebut kurang efisien dan kemungkinan kesalahan dalam input data masih dapat terjadi. Seperti proses pencatatan pemesanan menggunakan kertas, perhitungan menggunakan kalkulator dan transaksi penjualan ditulis pada buku. Maka itu untuk menyelesaikan permasalahan tersebut dibutuhkan sebuah aplikasi kasir yang dapat memudahkan dalam proses pemesanan, perhitungan dan transaksi secara akurat dengan aplikasi kasir berbasis web yang memiliki fitur login, transaksi penjualan, data produk, tambah produk, pengaturan dan keluar aplikasi. Proses pengembangan kami menggunakan metode waterfall dan untuk menggambarkan rancangan sistem kami menggunakan Unified Modeling Language (UML). Penerapan dengan menggunakan metode waterfall dapat memudahkan dalam menyelesaikan proses pengembangan aplikasi karena sudah adanya tahapan-tahapan pada metode tersebut.
\end{abstract}

Kata kunci: Aplikasi Kasir; Aplikasi Berbasis Web; Waterfall; UML; Unified Modelling Language

\section{Pendahuluan}

Bertambahnya ilmu pengetahuan dan teknologi pada kehidupan manusia menjadikan kebutuhan bagi manusia untuk terus memudahkan pekerjaan. Teknologi ditujukan untuk membantu berbagai jenis pekerjaan manusia untuk meningkatkan kemudahan, efektifas dan efesiensi (Taufiq, Magfiroh, Yusup, \& Yulianti, 2020).

Manfaat tersebut dapat dimanfaatkan pada berbagai aspek, hal ini juga dimanfaatkan pada proses kasir (Bakhri, Hanif, \& Haidir, 2020). Dengan pemanfaatan tersebut maka hasilnya akan lebih akurat dan cepat dan pemanfaatan tersebut mengurangi biaya serta menghemat waktu pengerjaan (Yudantoro, Suyanto, \& Chasanah, 2017). Tentu hal ini akan menjadi hal psositif bagi perusahaan juga bagi konsumen.

Saat ini proses bagian kasir di sebagian tempat masih dilakukan secara manual dengan mencatat pemesanan menggunakan kertas (Handayani, Hidayat, \& Taufiq, 2020) (Suminten, 2020). Tidak adanya informasi kejelasan tentang riwayat pemesanan di tempat tersebut dan human error masih sangat ditemukan, menjadikan hal ini 
tidak efisien (Muthohari, Bunyamin, \& Rahayu, 2016) (Waworuntu \& Lumba, 2017). Dengan demikian maka diperlukannya sebuah pengembangan aplikasi kasir yang dapat memudahkan dalam proses pemesanan dan informasi pemesanan.

Dalam pelayanan yang masih serba manual menyulitkan pemilik toko untuk memeriksa stok barang dan memeriksa hasil penjualan (Pamungkas \& Yuliansyah, 2017) (Sutara, 2017). Oleh karena itu, peneliti membuat rancang bangun sistem informasi data penjualan berbasis web menggunakan Framework Boostrap dengan bahasa pemrograman PHP (HyperText Preprocessor) dengan database MySQL (Handayani, Hidayat, \& Taufiq, 2020).

Tidak adanya informasi kejelasan tentang riwayat pemesanan di tempat tersebut dan human error masih sangat ditemukan, menjadikan hal ini tidak efisien. Dengan demikian maka diperlukannya sebuah pengembangan aplikasi kasir yang dapat memudahkan dalam proses pemesanan dan informasi pemesanan.

Penelitian pengembangan membuat rancangan pengembangan aplikasi kasir ini dengan menggunakan model waterfall dikarenakan persyaratan (requirement) dapat diidentifikasi secara lengkap diawal. Dengan model waterfall akan dapat memudahkan dalam tahap pengembangan karena dilakukan secara bertahap dan meminimalisir akan terjadinya kesalahan.

\section{Metodologi}

Penelitian dimulai dengan menggunakan metode observasi dan wawancara dengan pemilik percetakan, mengamati secara langsung proses pemesanan, pembayaran dan pengambilan barang, identifikasi masalah, kemudian melakukan analisa yang menghasilkan solusi atas masalah yang dihadapi. Proses pengembangan kami akan menggunakan metode waterfall. Adapun pengertian kasir adalah seseorang yang bekerja melayani transaksi penjualan (Saputra \& Anwar, 2017).

Metode waterfall ini dipilih karena metode yang paling mudah menurut kami untuk dipraktekan. Metode waterfall memiliki 5 tahapan, tahapan-tahapan tersebut nantinya akan dilakukan secara bertahap hingga selesai.

Requirement analysis and definition pada tahap ini kami menganalisa kebutuhan pengguna dan juga mengidentifikasi apa masalah yang dihadapi saat sedang melakukan proses transaksi kasir. Kami mendapati masalah yang terdapat pada proses sebelumnya yaitu seperti proses pencatatan pemesanan menggunakan kertas, perhitungan menggunakan kalkulator dan transaksi penjualan ditulis pada buku hal ini kurang efisien karena dilakukan secara manual dan juga memungkinkan terjadinya kesalahan dalam proses memasukkan data.

System and software design pada tahap ini, spesifikasi sistem dari kebutuhan pengguna yang didapat dari requirement analysis selanjutnya dianalisa kemudian diimplementasikan ke dalam bentuk desain pengembangan. Dari masalah yang ada kami mencoba untuk membuat sistem dengan desain yang dapat menampilkan produk sekaligus dapat menghitung harga produk tersebut.

Implementation and unit testing pada tahap ini rancangan aplikasi sistem diimplementasikan ke dalam bentuk rangkaian program dan pada tahap ini juga dilakukan pengujian dan pemeriksaan. Pengujian merupakan tahapan penting yang harus dilakukan untuk memberikan jaminan terhadap kualitas perangkat lunak yang dikembangkan (Muslimin, et al., 2020). Pertama kami membuat rancangan database terlebih dahulu dengan menggunakan aplikasi sublime, kemudian kami membuat sistem login, halaman utama, produk, pengaturan dan keluar aplikasi dengan menggunakan aplikasi notepad ++ .

Integration and system testing tahap ini mengumpulkan semua rangkaian program menjadi keseluruhan kemudian program tersebut dilakukan pemeriksaan dan pengujian sistem sepenuhnya untuk mengetahui apakah masih ada error atau bug pada sistem tersebut. Pengujian terhadap perangkat lunak sangat penting dilakukan dengan tujuan untuk memberikan jaminan kualitas perangkat lunak yang dihasilkan agar bebas dari terjadinya kesalahan (Debiyanti, Sutrisna, Budrio, Kamal, \& Yulianti, 2020). Kami mencoba menjalankan program tersebut dengan menggunakan aplikasi PHP.

Operation and maintenance tahap ini merupakan tahap akhir, sistem yang sudah jadi dioperasikan oleh pengguna. Jika masih terjadi kesalahan yang terdapat pada sistem tersebut maka bisa diperbaiki oleh pengembang. Sejauh penggunaan aplikasi ini, program dapat digunakan dengan cukup baik.

Pada tahap analisa untuk mengidentifikasi kebutuhan pengguna secara rinci, kami melakukan analisa identifikasi dengan menggunakan metode sebagai berikut:

1. Wawancara 
Melakukan tanya jawab langsung kepada pemilik tempat tentang sistem yang ada saat ini. Sistem yang saat ini sedang berjalan, yaitu dalam proses pemesanan order ditulis pada nota pemesanan dan penghitungan harga menggunakan kalkulator, tidak adanya identitas konsumen pada saat pengambilan barang, proses pembayaran, laporan pemesanan, dan pengambilan masih dilakukan secara manual.

2. Observasi

Mengamati langsung proses pemesanan, pembayaran dan pengambilan yang dilakukan pihak $\mathrm{CV}$ masih mencatat dengan buku dan pemesanan yang dilakukan dengan nota atau kwitansi sebagai bukti pemesanan.

Pengembangan aplikasi kasir dirancang dengan pemodelan Unified Modelling Language (UML) dan digambarkan dengan diagram pada Gambar 1.

Berdasarkan analisa yang kami lakukan untuk mengetahui identifikasi masalah dan kebutuhan pengguna yang diperoleh melalui wawancara dan observasi, kami mendapatkan beberapa rancangan proses untuk membentuk sistem jasa percetakan yang di gambarkan dalam bentuk use case diagram.

\section{Analisa Kelayakan}

Analisa kelayakan ini, kami lakukan analisa terhadap kelayakan program yang kami buat untuk dapat dijalankan dengan baik oleh pengguna. Proses yang masih manual sebelumnya akan dikerjakan dengan menggunakan proses dengan aplikasi kasir yang telah kami buat. Pada aplikasi yang kami buat akan memiliki fitur login, transaksi penjualan, data produk, tambah produk, pengaturan dan keluar aplikasi. Dan semua fitur tersebut akan bisa diakses oleh pemilik ataupun kasir. Kami membuat aplikasi tersebut menggunakan sublime dan menjalankannya melalui aplikasi PHP dengan database MySQL.

\section{Break Event Point}

Break event point adalah di mana suatu perusahaan tidak mendapat keuntungan dan juga tidak mendapat keuntungan (Jodinesa \& Sutopo, 2018). Penjabaran lebih jelasnya sebagai berikut:

1. Biaya tetap, baik ketika perusahaan sedang beroperasi ataupun tidak beroperasi.
Tabel 1. Biaya Tetap

\begin{tabular}{|l|l|r|}
\hline No & \multicolumn{1}{|c|}{ Biaya Tetap } & Jumlah (Rp) \\
\hline 1 & Biaya Gaji Pegawai & Rp.3.000.000 \\
\hline 2 & $\begin{array}{l}\text { Biaya Penyusutan Mesin } \\
\text { Percetakan }\end{array}$ & Rp.477.000 \\
\hline 3 & Biaya Penyusutan Komputer & Rp.212.500 \\
\hline 4 & Biaya Penyusutan Bangunan & Rp.1.099.500 \\
\hline 5 & Biaya Penyusutan Genset & Rp.258.250 \\
\hline 6 & Biaya Sewa Bangunan & Rp.500.000 \\
\hline & Jumlah & Rp.5.547.250 \\
\hline
\end{tabular}

Dari tabel di atas, diketahui bahwa biaya tetap per bulan yang terbesarnya adalah biaya penyusutan bangunan Rp.1.099.500 dan biaya tetap perbulan terkecilnya Rp.212.500 yaitu biaya penyusutan komputer, total biaya tetap perbulannya sebesar Rp.5.547.250.

2. Biaya Variabel, biaya ini tergantung pada volume produksinya.

Tabel 2. Biaya Variabel

\begin{tabular}{|l|l|l|}
\hline No & Biaya Variabel & Jumlah (Rp) \\
\hline 1 & Bahan Baku & Rp.930.000 \\
\hline 2 & Tinta & Rp.600.000 \\
\hline 3 & Biaya listrik & Rp.450.000 \\
\hline 4 & Biaya Internet & Rp.650.000 \\
\hline 5 & Lainnya & Rp.500.000 \\
\hline Jumlah & Rp.3.130.000 \\
\hline
\end{tabular}

Dari tabel di atas diketahui biaya variabel terbesar perbulannya sebesar Rp.930.000 yaitu bahan baku dan untuk biaya variabel terkecil perbulan sebesar Rp.450.000 yaitu biaya listrik, total biaya variabel perbulan sebesar Rp.3.130.000.

Dari uraian di atas dapat dijabarkan total prduksinya sebagai berikut:

Produksi $=625 \mathrm{~m}^{2}$

Harga $=$ Rp30.000

$625 \times 30.000$

Biaya Produksi

Keuntungan
Rp.18.750.000

Rp.8.677.250 -

Rp.10.072.750 
Dapat ditarik kesimpulan keuntungan toko percetakan sebesar Rp.10.072.750 per bulan.

\section{Use Case Diagram Aplikasi Kasir}

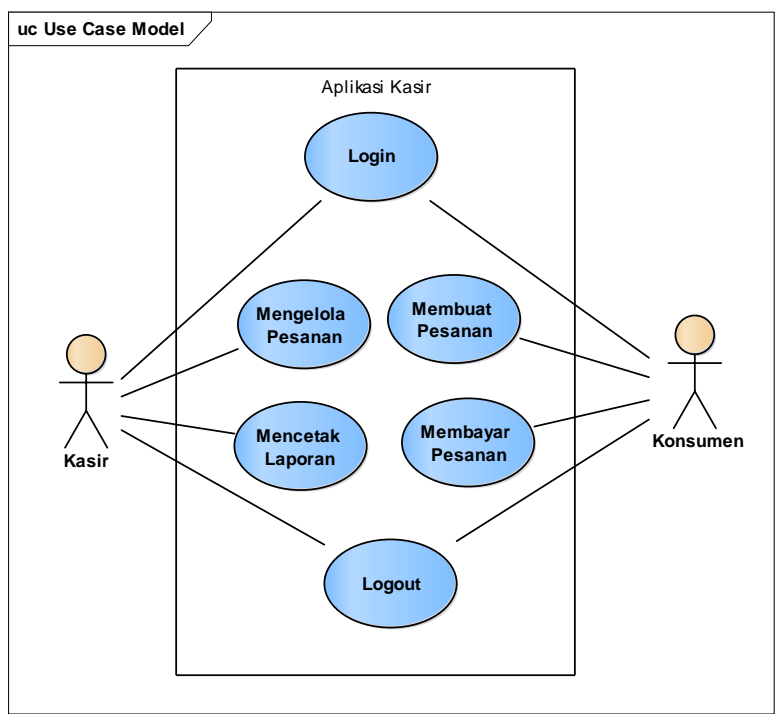

Gambar 1. Use Case Diagram Aplikasi Kasir

Pada use case aplikasi kasir ini menunjukan 2 actor yaitu kasir dan konsumen. Kasir berperan dalam menerima pesanan, membuat pesanan dan membuat laporan. Konsumen berperan dalam memesan barang dan membayar pesanan.

\section{Hasil dan Pembahasan}

Tahap analisa dan penerapan sebelumnya yang telah dilakukan menghasilkan aplikasi kasir dengan desain yang mudah digunakan. Pada aplikasi tersebut pemilik dan kasir dapat mengakses semua fungsional sistem seperti login, transaksi penjualan, data produk, tambah produk, pengaturan dan keluar aplikasi.

Pada saat transaksi penjualan, kasir akan memilih data barang yang sebelumnya sudah tersimpan di database kemudian memasukkan jumlah yang dipesan. Pada saat transaksi akan langsung terlihat kode produk, nama produk, jumlah, harga dan subtotal. Harga pada setiap produk yang tertera akan langsung otomatis terlihat karena sudah tersimpan dalam database sebelumnya. Data yang sudah dipilih pada transaksi juga dapat dibatalkan, diubah dan dihapus untuk memudahkan dalam transaksi jika konsumen membatalkan transaksinya tersebut atau memilih produk lain yang dapat dilihat pada Gambar 3 .
Pada tampilan halaman utama ini adalah halaman login untuk pengguna baik pemilik dan juga kasir yang bertugas dengan memasukkan username dan password yang sudah tersimpan di dalam sistem.

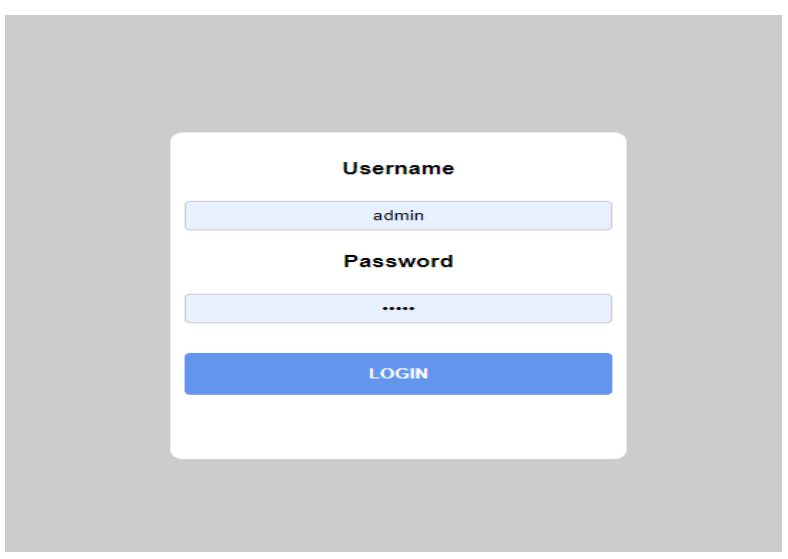

Gambar 2. Form Login

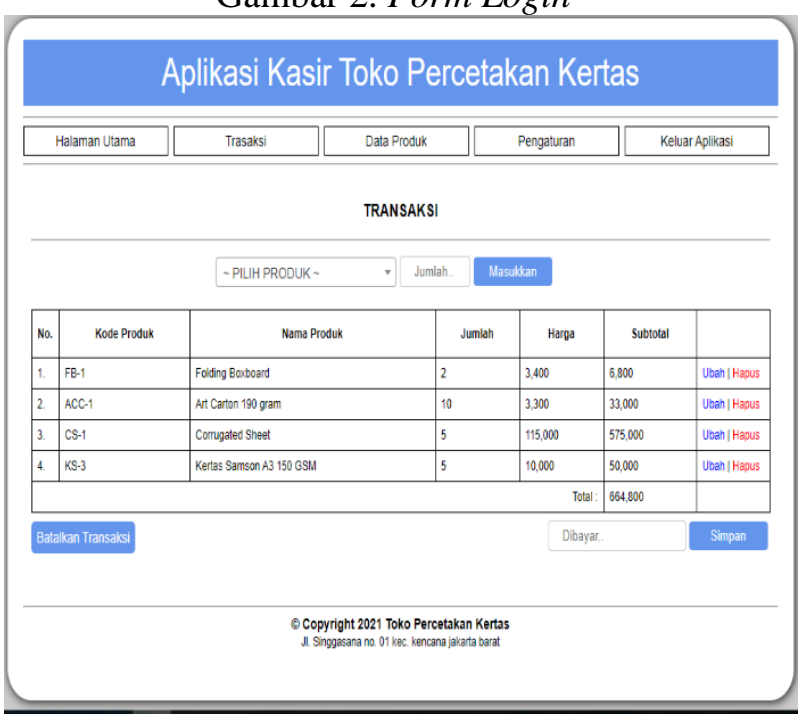

Gambar 3. Tampilan Halaman Transaksi

\section{Transaksi}

Pada tampilan transaksi gambar 3 terlihat data transaksi yang sedang diproses oleh kasir. Dengan memilih produk dan memasukkan jumlahnya maka akan terlihat harga dengan subtotal, sehingga memudahkan kasir tanpa menghitung kembali total produk yang dipesan.

\section{Tampilan Halaman Login}




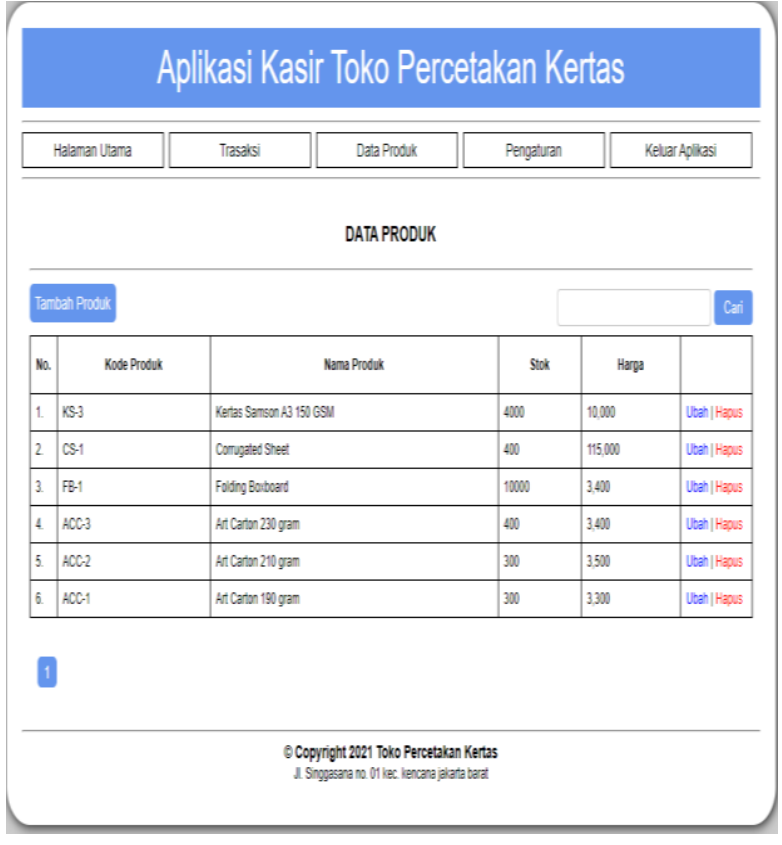

Gambar 4. Tampilan Data Produk

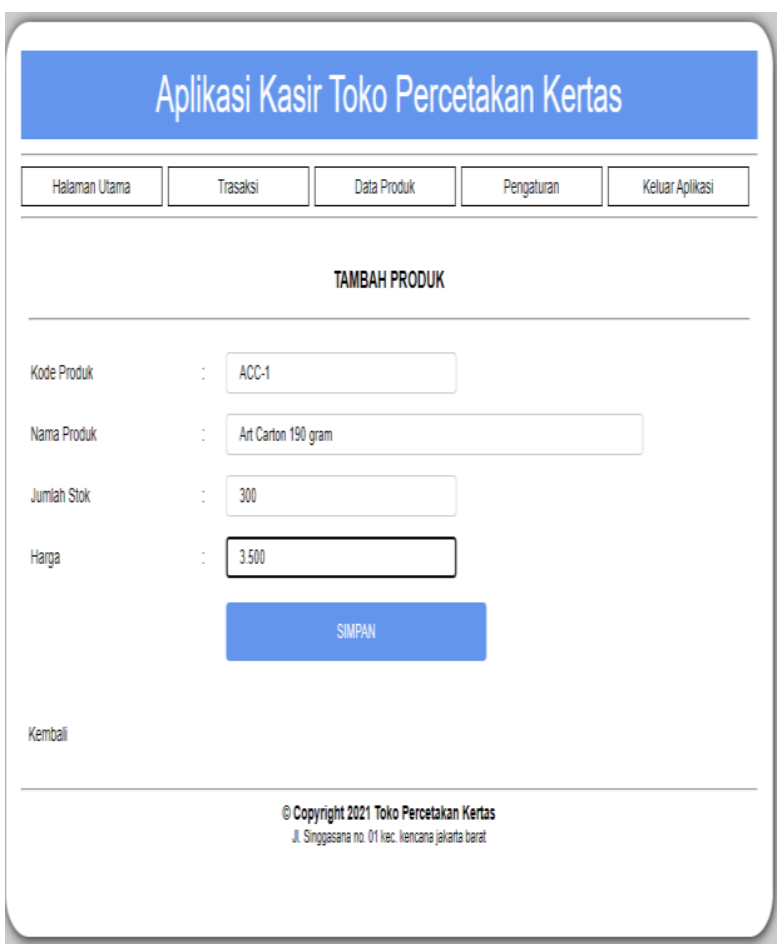

Gambar 5. Tampilan Tambah Produk

\section{Data Produk}

Pada data produk ini yang ada pada Gambar 4, akan terlihat semua data yang telah tersimpan pada sistem. Jika ada produk yang baru maka kasir dapat menambahkan produk tersebut. Kasir dapat menambahkan kode produk, nama produk, jumlah stok produk, harga, dan jika sudah selesai kasir tinggal menekan tombol simpan.

\section{Pengaturan}

Pada tampilan pengaturan ini, pemilik ataupun kasir dapat mengatur username, password, nama perusahaan dan alamat perusahaan. Jadi aplikasi kasir ini bisa dipakai pada segala bidang usaha bukan hanya percetakan saja.

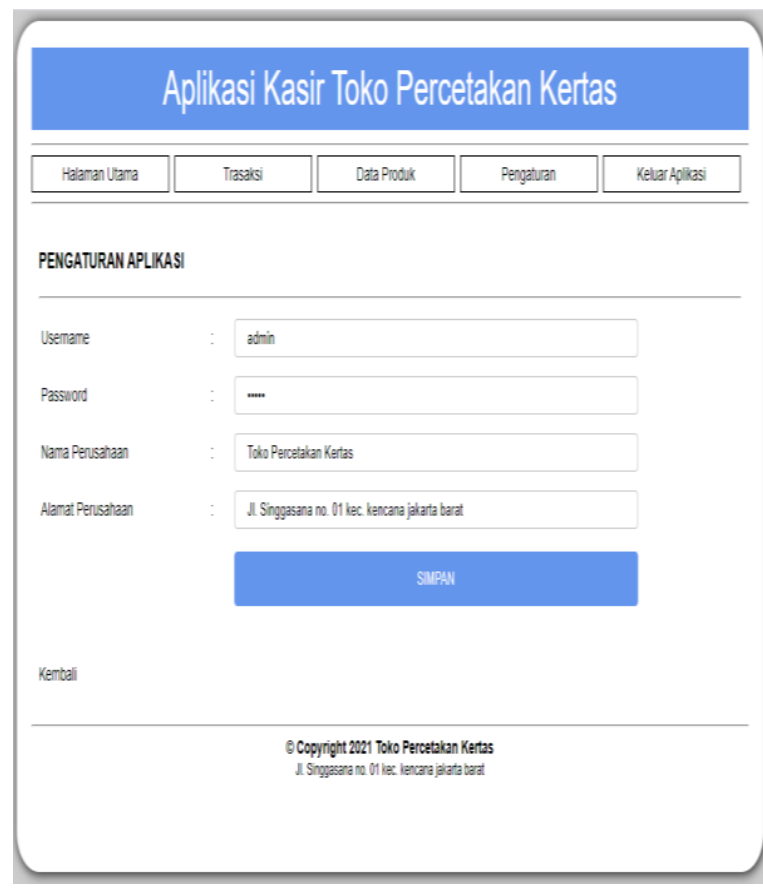

Gambar 6. Tampilan Pengaturan

\section{Keluar Aplikasi}

Keluar aplikasi digunakan jika kasir sudah selesai dengan tugasnya atau sedang waktunya istirahat. Jika kasir menekan tombol keluar aplikasi maka akan kembali kepada halaman login.

\section{Kesimpulan}

Berdasarkan pengembangan aplikasi kasir menggunakan metode waterfall dapat kami simpulkan sebagai berikut:

1. Penerapan dengan menggunakan metode waterfall dapat memudahkan dalam menyelesaikan proses pengembangan aplikasi karena sudah adanya tahapantahapan pada metode tersebut.

2. Proses transaksi penjualan lebih efisian dan memudahkan untuk dikerjakan tidak perlu menulis pada kertas lagi.

3. Dengan adanya adanya aplikasi kasir ini, pengguna dapat dengan mudah dalam menghitung pesanan karena sudah otomatis akan muncul dengan harga dan total. 
4. Dengan adanya aplikasi kasir ini, konsumen dapat dengan mudah membayar pada bagian kasir.

\section{Saran}

Pada kesimpulan yang didapat pada pengembangan aplikasi kasir ini dapat memudahkan dalam pengerjaan sistem transaksi penjualan, akan tetapi pengembangan ini masih banyak kekurangan pada sistem dan fitur yang ada, maka dari itu saran untuk pengembangan penlitian selanjutnya agar sistem yang telah ada bisa dikembangkan lebih baik lagi.

\section{Referensi}

Bakhri, S., Hanif, F., \& Haidir, A. (2020). Rancang Bangun Aplikasi Kasir Penjualan Susu Berbasis Web pada Alomgada Kids Jakarta. IJCIT (Indonesian Journal on Computer and Information Technology), 5(1), 47-54. doi:10.31294/ijcit.v5i1.6397

Debiyanti, D., Sutrisna, S., Budrio, B., Kamal, A. K., \& Yulianti, Y. (2020). Pengujian Black Box pada Perangkat Lunak Sistem Penilaian Mahasiswa Menggunakan Teknik Boundary Value Analysis. Jurnal Informatika Universitas Pamulang, 5(2), 162-166. doi:10.32493/informatika.v5i2.5446

Handayani, T., Hidayat, N., \& Taufiq, R. (2020). Rancang Bangun Sistem Informasi Data Penjualan Berbasis Web pada Kedai Payon Kopi. SENDIU (Seminar Nasional Multi Disiplin Ilmu) (pp. 188-193). Semarang: Universitas Stikubank.

Jodinesa, M. N., \& Sutopo, W. (2018). Aplikasi Metode Break Event Point Analysis Pada Engineering Economics : Studi Kasus. Seminar dan Konferensi Nasional IDEC (pp. 1-9). Surakarta: Universitas Sebelas Maret.

Muslimin, D. B., Kusmanto, D., Amilia, K. F., Ariffin, M. S., Mardiana, S., \& Yulianti, Y. (2020). Pengujian Black Box pada Aplikasi Sistem Informasi Akademik Menggunakan Teknik Equivalence Partitioning. Jurnal Informatika
Universitas Pamulang, 5(1), 19-25. doi:10.32493/informatika.v5i1.3778

Muthohari, A., Bunyamin, \& Rahayu, S. (2016). Pengembangan Aplikasi Kasir Pada Sistem Informasi Rumah Makan Padang Ariung. Jurnal Algoritma, 13(1), 157-163. doi:10.33364/algoritma/v.13-1.157

Pamungkas, G., \& Yuliansyah, H. (2017). Rancang Bangun Aplikasi Android Pos (Point Of Sale) Kafe Untuk Kasir Portable Dan Bluetooth Printer. Jurnal Sains dan Teknologi, 6(1), 199208. doi:10.23887/jst-undiksha.v6i1.8828

Saputra, A., \& Anwar, S. N. (2017). Rancang Bangun Sistem Informasi Kasir Dengan Menerapkan Metode Akuntansi Konsinyasi. Prosiding SINTAK (pp. 270-276). Semarang: Universitas Stikubank.

Suminten, S. (2020). Sistem Informasi Penjualan Aplikasi Kasir Berbasis Website pada Mart Serba Guna Blora. PROSISKO: Jurnal Pengembangan Riset dan Observasi Sistem Komputer, 7(2), 102107.

Sutara, B. (2017). Optimalisasi Aplikasi Transaksi Penjualan Berbasis Web Menggunakan Framework Codeigniter (Studi Kasus: Rumah Makan Tirta Sandi Sumedang). Jurnal Informatika: Jurnal Pengembangan IT (JPIT), 2(1), 1-5. doi:10.30591/jpit.v2i1.433

Taufiq, R., Magfiroh, D. A., Yusup, D., \& Yulianti, Y. (2020). Analisis dan Desain Sistem Informasi Pembayaran Sumbangan Pembinaan Pendidikan (SPP) di SMK Avicena Rajeg. Jurnal Teknologi Sistem Informasi dan Aplikasi, 3(1), 15-21. doi:10.32493/jtsi.v3i1.4308

Waworuntu, A., \& Lumba, E. (2017). Pengembangan Aplikasi Kasir dan Pengelolaan Stok. Seminar Nasional Sains dan Teknologi, 1-6.

Yudantoro, T. R., Suyanto, B., \& Chasanah, A. U. (2017). Sistem Informasi Manajemen Toko Berbasis Web dengan Menggunakan Barcode Scanner untuk Entri Data. JTET (Jurnal Teknik Elektro Terapan), 6(1), 10-17. doi:10.32497/jtet.v6i1.1186 